\title{
Knowledge Management using Ontology Based Tantra Framework for Good Governance
}

\author{
Shreekanth M. Prabhu*, K. N. Balasubramanya Murthy and S. Natarajan \\ PES University, 100 Feet Outer Ring Road, Banashankari $3^{\text {rd }}$ Stage, Banashankari Bangalore - 560085, India; \\ shreekanthprabhu@pes.edu, vice.chancellor@pes.edu, natarajan@pes.edu
}

\begin{abstract}
This paper proposes ontology-based Tantra Framework that accommodates Societal Information in an orderly, compact and unified manner to achieve Good Governance. In this work, Zachman Framework for Enterprise Architecture is used as reference and it is extended to address information operating at societal scale. The complexity of social information gets accentuated due to myriad possibilities of relationships, say compared to information pertaining to an Enterprise. In light of that, two additional columns namely relationships and relators have been added to Zachman Framework in Tantra Framework. The existing six columns of Zachman Framework namely who, what, how, when, where and why are interpreted as People, Assets/Attributes, Process, Event, Location and Objectives respectively. In addition to the six interrogatives of Zachman Framework that are ontology based, the concept of relationships and relators has been derived from The Unified Foundational Ontology. Even though Zachman considered his framework as Ontology, some researchers regarded it as taxonomy. Tantra Framework has addressed that perceived gap by extending the Zachman Framework by adding two additional columns. The utility of Tantra Framework is analyzed by applying it to a set of Application Scenarios pertaining to People and Locations information, Revenue Capture, Social Benefit Coverage Analysis, Financial Inclusion and Metrics analysis. Tanta Framework interoperates with Balanced Score Card approach to set objectives, Theory of Change to lay out a process of change and Bartels' theory of Market Separations to assess the access barriers within Society. This research study is focused on Indian context. Tantra Framework relies on eliciting the inherent order in social information to make it complete, correct and current. For example, in Chemistry, discovery of periodic table by Mendeleev led to a unifying scheme which not only captured the present but allowed for place-holders for future discoveries. A similar focus on eliciting inherent order in social information, can potentially reveal latent 'facts', 'truths' and 'relationships.
\end{abstract}

Keywords: Financial Inclusion, Framework, Good Governance, Knowledge Management, Ontology, Theory of Separations

\section{Introduction}

Over the years, the Government of India has faced many Governance challenges. Some of the challenges are:

- Delivering services to needy people within reasonable time, serving the neediest first,

- Ensuring that all the people pay their taxes,

- Ensuring that tax revenue is spent in an optimal manner, and

- Ensuring that economic and social indicators make strong and sustained progress.
In this paper the objective is to define a framework that addresses Good Governance objectives.

From a researcher's view-point, "a framework is an organized structure of ideas, concepts, and other things that are involved. A well-developed framework should be coherent and serve as a communication tool to stakeholders".

\subsection{Good Governance}

Good Governance is human-centric in contrast with process-centric nature of E-Governance. 
Kautilya in his treatise Arthashastra elaborated the traits of the King of a well governed state thus: "in the happiness of his subjects lies his happiness, in their welfare his welfare, whatever pleases himself, he does not consider good, but whatever pleases his subjects he considers as good".

Mahatma Gandhi propounded the concept of "Su-raj". As per him "Good governance" has the following eight attributes, which link it to its Citizens: 1. Accountable, 2. Transparent, 3. Responsive, 4. Equitable and inclusive, 5. Effective and Efficient, 6. Follows the rule of law, 7. Participatory, and 8. Consensus oriented.

To achieve good governance in a human-centric manner we need to fulfill aspirations of people. Here Maslow's motivation hierarchy come handy (Figure 1).

A good governance model that can address different needs of people is shown in Table 1 (Prabhu, 2017).

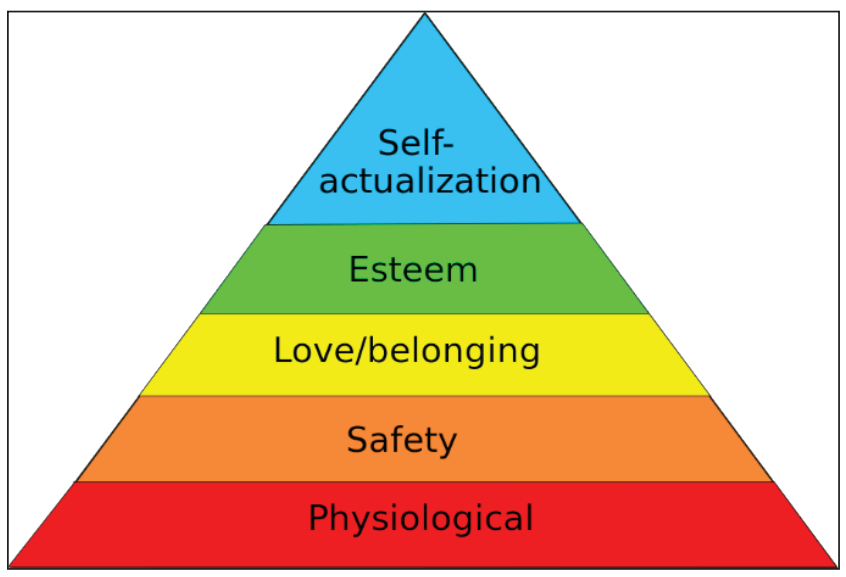

Figure 1. Maslow's motivation hierarchy.

Table 1. Good governance model

\begin{tabular}{|l|l|}
\hline \multicolumn{1}{|c|}{ Layer (sub-model) } & \multicolumn{1}{c|}{ Focus } \\
\hline $\begin{array}{l}\text { Strategy and } \\
\text { Competitiveness Model }\end{array}$ & $\begin{array}{l}\text { To gain strong global position, } \\
\text { power and prosperity }\end{array}$ \\
\hline National Innovation Model & $\begin{array}{l}\text { Business model innovation, } \\
\text { technology innovation, new } \\
\text { competencies and processes }\end{array}$ \\
\hline Common Economic Model & $\begin{array}{l}\text { Ecosystem that balances } \\
\text { interests and serves optimally }\end{array}$ \\
\hline
\end{tabular}

\begin{tabular}{|l|l|}
\hline 4 D's development model & $\begin{array}{l}\text { Financial Inclusion, Balanced } \\
\text { Growth }\end{array}$ \\
\hline Safety and security model & $\begin{array}{l}\text { Physical, financial, social, } \\
\text { emotional well-being }\end{array}$ \\
\hline Empowerment Model & $\begin{array}{l}\text { Access to nutrition, education, } \\
\text { health-care and employment/ } \\
\text { livelihood }\end{array}$ \\
\hline Core Governance Model & $\begin{array}{l}\text { Access to information, } \\
\text { Access to timely service and } \\
\text { opportunity to participate }\end{array}$ \\
\hline
\end{tabular}

\subsection{Research Problem}

The research reported in this paper closely relates to the task of arriving at Architecture for complex system. According to Crawley, "system architecture is the embodiment of concept: the allocation of physical/ informational function to elements of form, and the definition of interfaces among the elements and with the surrounding context" (Crawley, 2007; Crawley, et al., 2004). Taking a cue from this definition, our research problem needs to dwell on three important questions:

- How is information organized? (Form),

- How is information used? (Function), and

- How is the form mapped to function? (Concept).

Table 2 elaborates on the modeling of Research Problem using Function-Form-Concept paradigm.

Rest of the paper is structured as follows:

Section 2 dwells on Frameworks, Models and Ontology in the context of managing knowledge pertaining to complex systems such as Governance Systems.

Section 3 describes the Ontology-based Tantra Framework.

Section 4 describes a set of Application Scenarios that can take advantage of Tantra Framework.

Section 5 describes the Knowledge Management Methodology using Tantra Framework with the above application scenarios in mind.

Section 6 concludes the paper. 
Table 2. Modeling research problem using Function-Form-Concept paradigm

\begin{tabular}{|c|c|c|}
\hline Form & Function & Concept \\
\hline $\begin{array}{l}\text { - Choose an appropriate framework } \\
\text { to capture dimensions and level of } \\
\text { details in each dimension. }\end{array}$ & $\begin{array}{l}\text { - The Framework should store social } \\
\text { information in an orderly and } \\
\text { compact manner. }\end{array}$ & $\begin{array}{l}\text { - A mechanism is needed to visualize } \\
\text { the social information and to update } \\
\text { it with new data. }\end{array}$ \\
\hline $\begin{array}{l}\text { - Model each dimension to ensure } \\
\text { compactness. Considering the } \\
\text { discrete information space, each } \\
\text { dimension can be modeled as a set. }\end{array}$ & $\begin{array}{l}\text { - The framework should be able to } \\
\text { address operations needed to manage } \\
\text { social information }\end{array}$ & $\begin{array}{l}\text { A shared social information } \\
\text { infrastructure can be an enabler for } \\
\text { Good Governance. }\end{array}$ \\
\hline $\begin{array}{l}\text { - Establish a mechanism to define } \\
\text { relationships across dimensions. }\end{array}$ & $\begin{array}{l}\text { - The framework should help achieve } \\
\text { good governance and social change } \\
\text { objectives, by inter-operating with } \\
\text { appropriate models. } \\
\text { - A mechanism is needed to validate } \\
\text { the state of "good governance" } \\
\text { using appropriate metrics. }\end{array}$ & \\
\hline
\end{tabular}

\section{Frameworks, Models and Ontology}

This section discusses Frameworks, Models and approaches to arrive at a useful Ontology for Tantra Framework.

\subsection{Zachman Framework}

Zachman Framework (Zachman, 2003) has rows and columns that can capture information in a holistic and comprehensive manner. Zachman Framework is illustrated in Table 3.

Table 3. Zachman Framework (Zachman 2013)

\begin{tabular}{|c|c|c|c|c|c|c|}
\hline & What & How & Where & Who & When & Why \\
\hline Contextual & $\begin{array}{l}\text { List of things } \\
\text { important to } \\
\text { business }\end{array}$ & $\begin{array}{l}\text { List of core } \\
\text { business } \\
\text { processes }\end{array}$ & $\begin{array}{l}\text { List of business } \\
\text { locations }\end{array}$ & $\begin{array}{l}\text { List of important } \\
\text { organizations }\end{array}$ & List of Events & $\begin{array}{l}\text { List of business } \\
\text { goals Strategies }\end{array}$ \\
\hline Conceptual & $\begin{array}{l}\text { Conceptual } \\
\text { data / object } \\
\text { model }\end{array}$ & $\begin{array}{l}\text { Business } \\
\text { Process Model }\end{array}$ & $\begin{array}{l}\text { Business Logistics } \\
\text { System }\end{array}$ & $\begin{array}{l}\text { Work Flow } \\
\text { Model }\end{array}$ & $\begin{array}{l}\text { Master } \\
\text { Schedule }\end{array}$ & Business Plan \\
\hline Logical & $\begin{array}{l}\text { Logical Data } \\
\text { Model }\end{array}$ & $\begin{array}{l}\text { System } \\
\text { Architecture } \\
\text { Model }\end{array}$ & $\begin{array}{l}\text { Distributed } \\
\text { System } \\
\text { Architecture }\end{array}$ & $\begin{array}{l}\text { Human Interface } \\
\text { Architecture }\end{array}$ & $\begin{array}{l}\text { Processing } \\
\text { Structure }\end{array}$ & $\begin{array}{l}\text { Business Role } \\
\text { Model }\end{array}$ \\
\hline Physical & $\begin{array}{l}\text { Physical data/ } \\
\text { Class model }\end{array}$ & $\begin{array}{l}\text { Technology } \\
\text { Design Model }\end{array}$ & $\begin{array}{l}\text { Technology } \\
\text { Architecture }\end{array}$ & $\begin{array}{l}\text { Presentation } \\
\text { Architecture }\end{array}$ & $\begin{array}{l}\text { Control } \\
\text { Structure }\end{array}$ & Rule Design \\
\hline Detailed & $\begin{array}{l}\text { Data } \\
\text { Definitions }\end{array}$ & Program & $\begin{array}{l}\text { Network } \\
\text { Architecture }\end{array}$ & $\begin{array}{l}\text { Security } \\
\text { Architecture }\end{array}$ & $\begin{array}{l}\text { Timing } \\
\text { Definition }\end{array}$ & Rule Specification \\
\hline $\begin{array}{l}\text { Functioning } \\
\text { Enterprise }\end{array}$ & Usable Data & $\begin{array}{l}\text { Working } \\
\text { Function }\end{array}$ & Usable network & $\begin{array}{l}\text { Functioning } \\
\text { Organization }\end{array}$ & $\begin{array}{l}\text { Implemented } \\
\text { Schedule }\end{array}$ & Working Strategy \\
\hline
\end{tabular}


Here the columns are primary interrogatives - who, what, when, where, how and why. The rows represent the perspectives of Planner, Owner, Designer, Builder, Implementer and Operator respectively (Zachman, 2007).

\subsection{Unified Foundational Ontology (UFO)}

Ontology is extremely important when building a generic framework such as Tantra Framework. The Aspects of Zachman Framework derive from Ontology. The UFO (Santos Jr, et.al., 2013) constructs are explained in Table 4 and 5.

Table 4. UFO concepts

\begin{tabular}{|c|c|c|c|c|c|c|c|c|c|}
\hline Level & 1 & 2 & 3 & 4 & 4 & 5 & 5 & 6 & 7 \\
\hline Concept & $\begin{array}{l}\text { Basic } \\
\text { Elements }\end{array}$ & $\begin{array}{l}\text { Univer- } \\
\text { sals }\end{array}$ & $\begin{array}{l}\text { Indivi- } \\
\text { duals }\end{array}$ & $\begin{array}{l}\text { Endu- } \\
\text { rants }\end{array}$ & $\begin{array}{l}\text { Perdu- } \\
\text { rants }\end{array}$ & Substan-tial & Moment & $\begin{array}{l}\text { Intrinsic } \\
\text { Moment }\end{array}$ & $\begin{array}{l}\text { Rela-tional } \\
\text { Moment } \\
\text { (Relator) }\end{array}$ \\
\hline Description & $\begin{array}{l}\text { Univer-sals } \\
\text { or Indivi- } \\
\text { duals }\end{array}$ & $\begin{array}{l}\text { Named } \\
\text { level in } \\
\text { Zachman }\end{array}$ & $\begin{array}{l}\text { Instan- } \\
\text { tiate } \\
\text { Univer- } \\
\text { sals }\end{array}$ & $\begin{array}{l}\text { Type of } \\
\text { Indivi- } \\
\text { duals }\end{array}$ & $\begin{array}{l}\text { Events } \\
\text { that make } \\
\text { up pro- } \\
\text { cesses }\end{array}$ & $\begin{array}{l}\text { Objects } \\
\text { that exist } \\
\text { independently }\end{array}$ & $\begin{array}{l}\text { Exist only } \\
\text { if bearer } \\
\text { exists }\end{array}$ & $\begin{array}{l}\text { Depend } \\
\text { on Single } \\
\text { Entity }\end{array}$ & $\begin{array}{l}\text { Moments } \\
\text { depend on } \\
\text { other entities } \\
\text { in addi-tion to } \\
\text { the bearer }\end{array}$ \\
\hline Examples & & People & & $\begin{array}{l}\text { House, } \\
\text { Person, } \\
\text { Moon, } \\
\text { Enter- } \\
\text { prise }\end{array}$ & $\begin{array}{l}\text { Busi-ness } \\
\text { pro-cesses, } \\
\text { Enroll- } \\
\text { ment pro- } \\
\text { cesses }\end{array}$ & $\begin{array}{l}\text { Person, } \\
\text { a house, } \\
\text { a planet, and } \\
\text { the rolling } \\
\text { stones }\end{array}$ & $\begin{array}{l}\text { John's } \\
\text { weight, } \\
\text { John and } \\
\text { Mary's } \\
\text { marri-age }\end{array}$ & $\begin{array}{l}\text { Colour of } \\
\text { some-thing } \\
\text { Temperature } \\
\text { of some } \\
\text { object }\end{array}$ & $\begin{array}{l}\text { Employ-ment } \\
\text { with employer. } \\
\text { Mary's } \\
\text { marriage with } \\
\text { John }\end{array}$ \\
\hline
\end{tabular}

Table 5. UFO relations

\begin{tabular}{|l|l|l|l|l|l|}
\hline Concept & $\begin{array}{l}\text { Independent } \\
\text { Intrinsic } \\
\text { Moments }\end{array}$ & $\begin{array}{l}\text { Dependent } \\
\text { Intrinsic } \\
\text { Moments }\end{array}$ & $\begin{array}{l}\text { Formal } \\
\text { Relation }\end{array}$ & $\begin{array}{l}\text { Material Relations/ } \\
\text { Domain Relation }\end{array}$ & Relator \\
\hline Examples & $\begin{array}{l}\text { Size and colour } \\
\text { of an object }\end{array}$ & $\begin{array}{l}\text { Colour and } \\
\text { brightness of an } \\
\text { object }\end{array}$ & $\begin{array}{l}\text { Village } \\
\text { belonging to a } \\
\text { District. Paul's } \\
\text { headache. }\end{array}$ & $\begin{array}{l}\text { Working at, being } \\
\text { enrolled at, and being } \\
\text { the husband of. Medical } \\
\text { treatment to Paul }\end{array}$ & $\begin{array}{l}\text { An enrollment connects a student } \\
\text { Government Department/policy/ } \\
\text { process connects a citizen with } \\
\text { benefit or privilege. }\end{array}$ \\
\hline
\end{tabular}

\subsection{Balanced Scorecard}

A commercial enterprise can be managed and led using a balanced score-card framework (Kaplan, 2010). It is possible to apply the same approach to Government. The same four perspectives may be applicable, namely,

- Financial,

- Customer (Citizen/Community/Business),

- Internal Business (Process of Governance), and

- Learning and Growth (Innovation and strategy).

The score card can be created and tracked in terms of Strategies, Objectives and metrics in line with mission and vision of an organization as illustrated Figure 2.

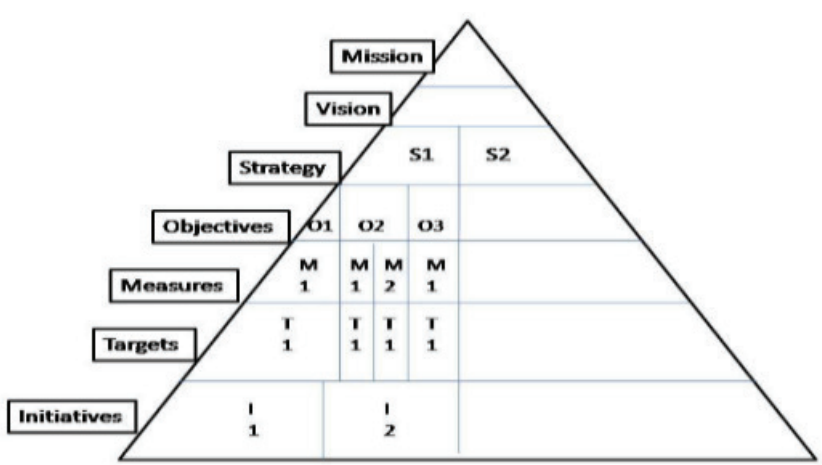

Figure 2. Balanced scorecard pyramid (Kaplan and Norton 1996).

In the last couple of decades there is focus on Ethical Perspective, as yet another perspective. This applies to businesses as well as society. 


\subsection{Theory of Change}

Kurt Lewin famously said, "There is nothing more practical than good theory". Theory of Change (Weiss, 1995) is essentially a comprehensive description and illustration of how and why a desired change is expected to happen in a specific context. It does this by first identifying the desired long-term goals and then works back from these to identify all the conditions (outcomes) that must be in place (and how these relate to one another causally) for the goals to occur. This leads to better planning, evaluation and monitoring of the initiatives.

\subsection{Theory of Separations}

Major objective of Governance is economic development. Here we would like to leverage ideas from Bartels theory of market separations (Bartels, 1968). Bartels identified four different separations that come in the way of marketdevelopment.

- Spatial separation or the physical distances between producers and consumers,

- Temporal separation or the time difference between production and consumption,

- Informational separation or the informational asymmetry between producers and consumers related to products and market conditions, and

- Financial separation or the lack of consumers' purchasing power when they are willingness to fulfill their needs".

Certain researchers have added Knowledge/Capability based separation as the $5^{\text {th }}$ separation (Tarafdar \& Singh, 2011).

\section{Ontology-based Tantra Framework}

The name Tantra Framework is chosen to reflect enormous connectivity of information through the framework. Etymologically in Sanskrit "tantram", literally means "loom, warp," hence, figuratively, "groundwork, system, doctrine".

Tantra Framework extends Zachman by adding two additional columns namely relators and relationships. The relationship column is used to represent any relationship which may correspond to a data-map or structured map, between framework columns. A relator column is added to represent any entity/concept that is integral part of any relationship. Yet another column namely separations is used to represent lack of relationship or the level of difficulty to access the relationship.

The aspects of Tantra Framework can be used to express social information as follows:

- People (Who),

- Places/Addresses/Locations/Zones (Where),

- Assets/Attributes (What),

- Events (When),

- Processes (for enrolment, intervention) (How),

- Metrics to measure development (Why),

- Relationships (between aspects),

- Relators (enable relationships), and

- Separations (express lack of or difficulty of establishing a relationship).

In addition, under "Who" aspect, we can model communities, categories of people as well as businesses and institutions. The Table 6, gives the view of Tantra Framework.

Table 6. Tantra framework

\begin{tabular}{|c|c|c|c|c|c|c|c|c|c|}
\hline \multirow[b]{2}{*}{ Perspectives } & \multicolumn{9}{|c|}{ Aspects } \\
\hline & Who & Where & What & When & How & Why & $\begin{array}{l}\text { Relation- } \\
\text { ships }\end{array}$ & Rela-tors & $\begin{array}{l}\text { Separa- } \\
\text { tions }\end{array}$ \\
\hline $\begin{array}{l}\text { Contextual (Named } \\
\text { and Scoped) }\end{array}$ & & & & & & & & & \\
\hline Conceptual (Defined) & & & & & & & & & \\
\hline Logically Designed & & & & & & & & & \\
\hline $\begin{array}{l}\text { Physically Configured } \\
\text { (Schema) }\end{array}$ & & & & & & & & & \\
\hline Detailed/Instantiated) & & & & & & & & & \\
\hline
\end{tabular}


Tantra Framework is modeled using Neo4J graph database. Here nodes contain properties (key-value pairs). Nodes can be labeled with one or more labels. Relationships are named and directed, and can also contain properties

Tantra Framework as defined above can be converted into a normative framework by interoperating with models that can help achieve Good Governance. Here Goals can be set using Balanced Scorecard Framework and interventions can be modeled and managed through Theory of Change Framework. The Separations can be expressed by drawing on Bartels' Theory of Separations in Figure 3.
In Tantra Framework, as in Zachman Framework, every aspect goes through the process of reification. Table 7 describes how People Domain is reified.

\begin{tabular}{|l|}
\hline Goals (Balanced Scorecard) \\
\hline Interventions (Theory of Change) \\
\hline Networks (Structured Maps) and \\
Separations (Disconnects) \\
\hline Relations (Aspects) \\
\hline Domains/Roles/Entity Sets (Instances) \\
\hline Discrete Information Space \\
\hline
\end{tabular}

Figure 3. Tantra framework with interoperating models.

Table 7. Reification of people domain

\begin{tabular}{|c|c|c|c|c|c|}
\hline Pers-pective & All people & Citizens & Residents & Resident Aliens & Resident Citizens \\
\hline $\begin{array}{l}\text { Named } \\
\text { (Identified \& } \\
\text { Contextualized) }\end{array}$ & $\begin{array}{l}\text { All the people } \\
\text { known and to } \\
\text { be known to the } \\
\text { framework. }\end{array}$ & $\begin{array}{l}\text { People who are } \\
\text { citizens }\end{array}$ & $\begin{array}{l}\text { People who are } \\
\text { residents }\end{array}$ & $\begin{array}{l}\text { People who are } \\
\text { resident but alien }\end{array}$ & Resident Citizens \\
\hline $\begin{array}{l}\text { Defined } \\
\text { (Conceptually } \\
\text { Struc-tured) }\end{array}$ & $\begin{array}{l}\text { What makes one } \\
\text { a member of this } \\
\text { domain/role }\end{array}$ & $\begin{array}{l}\text { What makes one } \\
\text { a member of this } \\
\text { domain/role }\end{array}$ & $\begin{array}{l}\text { What makes one } \\
\text { a member of this } \\
\text { domain/ role }\end{array}$ & $\begin{array}{l}\text { What makes one } \\
\text { a member of this } \\
\text { domain/role }\end{array}$ & $\begin{array}{l}\text { What makes one a } \\
\text { member of this domain/ } \\
\text { role }\end{array}$ \\
\hline $\begin{array}{l}\text { Logically } \\
\text { Designed }\end{array}$ & $\begin{array}{l}\text { Related attributes } \\
\text { that map to other } \\
\text { aspects. }\end{array}$ & $\begin{array}{l}\text { Related attributes } \\
\text { that map to other } \\
\text { aspects }\end{array}$ & $\begin{array}{l}\text { Related attributes } \\
\text { that map to other } \\
\text { aspects. }\end{array}$ & $\begin{array}{l}\text { Related attributes that } \\
\text { map to other aspects. }\end{array}$ & $\begin{array}{l}\text { Related attributes that } \\
\text { map to other aspects. }\end{array}$ \\
\hline Configured & $\begin{array}{l}\text { Representation in } \\
\text { Graph database } \\
\text { as nodes and } \\
\text { edges. }\end{array}$ & $\begin{array}{l}\text { Representation in } \\
\text { Graph database } \\
\text { as nodes and } \\
\text { edges. }\end{array}$ & $\begin{array}{l}\text { Representation in } \\
\text { Graph database as } \\
\text { nodes and edges. }\end{array}$ & $\begin{array}{l}\text { Representation in } \\
\text { Graph database as } \\
\text { nodes and edges. }\end{array}$ & $\begin{array}{l}\text { Representation in Graph } \\
\text { database as nodes and } \\
\text { edges. }\end{array}$ \\
\hline Instan-tiated & $\begin{array}{l}\text { Instantiate with } \\
\text { unique ID. }\end{array}$ & $\begin{array}{l}\text { Instantiate with } \\
\text { unique ID. }\end{array}$ & $\begin{array}{l}\text { Instantiate with } \\
\text { unique ID. }\end{array}$ & $\begin{array}{l}\text { Instantiate with } \\
\text { unique ID. }\end{array}$ & $\begin{array}{l}\text { Instantiate with unique } \\
\text { ID. }\end{array}$ \\
\hline
\end{tabular}

Table 8. Reification of addresses

\begin{tabular}{|l|l|l|l|l|l|}
\hline & Residential address & $\begin{array}{l}\text { General Address/ } \\
\text { Location }\end{array}$ & $\begin{array}{l}\text { Commercial } \\
\text { Address }\end{array}$ & $\begin{array}{l}\text { Institutional } \\
\text { address }\end{array}$ & $\begin{array}{l}\text { Address for public/ civic } \\
\text { amenity }\end{array}$ \\
\hline $\begin{array}{l}\text { Named } \\
\text { (Identified) }\end{array}$ & $\begin{array}{l}\text { Idea named with } \\
\text { context }\end{array}$ & $\begin{array}{l}\text { Idea named with } \\
\text { context }\end{array}$ & $\begin{array}{l}\text { Idea named with } \\
\text { context }\end{array}$ & $\begin{array}{l}\text { Idea named with } \\
\text { context }\end{array}$ & Idea named with context \\
\hline $\begin{array}{l}\text { Defined } \\
\text { (Conceptually } \\
\text { Structured) }\end{array}$ & $\begin{array}{l}\text { Concept of } \\
\text { Residential address. } \\
\text { Membership criteria, } \\
\text { entry and exit }\end{array}$ & $\begin{array}{l}\text { Concept of Generic } \\
\text { address or location }\end{array}$ & $\begin{array}{l}\text { Concept of } \\
\text { Commercial } \\
\text { address. Entry } \\
\text { and exit criteria. }\end{array}$ & $\begin{array}{l}\text { Concept of } \\
\text { Institutional } \\
\text { Address } \\
\text { Membership } \\
\text { Criteria }\end{array}$ & $\begin{array}{l}\text { Concept of utility/ } \\
\text { amenity -playground, } \\
\text { park. }\end{array}$ \\
\hline $\begin{array}{l}\text { Logically } \\
\text { Designed }\end{array}$ & $\begin{array}{l}\text { Attributes of } \\
\text { Residential } \\
\text { addresses }\end{array}$ & $\begin{array}{l}\text { Attributes of } \\
\text { Generic addresses }\end{array}$ & $\begin{array}{l}\text { Attributes of } \\
\text { commercial } \\
\text { addresses. }\end{array}$ & $\begin{array}{l}\text { Attributes of } \\
\text { Institutional } \\
\text { addresses }\end{array}$ & Attributes of amenities. \\
\hline
\end{tabular}




\begin{tabular}{|l|l|l|l|l|l|}
\hline Configured & $\begin{array}{l}\text { Schema for } \\
\text { Residential } \\
\text { addresses }\end{array}$ & $\begin{array}{l}\text { Schema for storing } \\
\text { generic addresses }\end{array}$ & $\begin{array}{l}\text { Schema for } \\
\text { commercial } \\
\text { address }\end{array}$ & $\begin{array}{l}\text { Schema for } \\
\text { institutional } \\
\text { addresses }\end{array}$ & $\begin{array}{l}\text { Schema for storing } \\
\text { details about address }\end{array}$ \\
\hline Instantiated & $\begin{array}{l}\text { Instantiate with } \\
\text { unique ID (Unique } \\
\text { ID+ Address ID) }\end{array}$ & $\begin{array}{l}\text { Instantiate with } \\
\text { Unique ID (GPS IS?) }\end{array}$ & $\begin{array}{l}\text { Instantiate with } \\
\text { Unique ID }\end{array}$ & $\begin{array}{l}\text { Instantiate with } \\
\text { Unique ID }\end{array}$ & $\begin{array}{l}\text { Instantiate with Unique } \\
\text { ID }\end{array}$ \\
\hline
\end{tabular}

Table 8 describes how the Addresses are reified. The addresses in turn are located in Zones or Geographic contexts which are uniquely identified.

Table 9 covers asset perspectives. The assets belong to "what" Aspect. In the same manner Loans, Taxed and duties paid/payable can be modeled in the Tantra Framework under "What" aspect. This can help get a complete financial profile of borrowers.

Table 10 covers the reification of relationships and relators and Table 11 covers separations with access to Formal Credit.

Table 9. Reification of assets

\begin{tabular}{|c|c|c|c|}
\hline Assets & Owned House & Vehicles & Land \\
\hline Named (Identified) & Idea Named with context & Idea Named with context & Idea Named with context \\
\hline $\begin{array}{l}\text { Defined (Conceptually } \\
\text { Structured) }\end{array}$ & $\begin{array}{l}\text { Concept, how this comes } \\
\text { about, through allotment, } \\
\text { transfer, inheritance. Part- } \\
\text { ownership }\end{array}$ & $\begin{array}{l}\text { Concept, how this comes } \\
\text { about, through allotment, } \\
\text { transfer, inheritance. }\end{array}$ & $\begin{array}{l}\text { Concept, how this comes about, } \\
\text { through allotment, transfer, inheritance. } \\
\text { Part-ownership }\end{array}$ \\
\hline Logically Designed & $\begin{array}{l}\text { Attributes like location, size, } \\
\text { related events }\end{array}$ & $\begin{array}{l}\text { Attributes like Type, Related } \\
\text { events }\end{array}$ & $\begin{array}{l}\text { Attributes like location, size, related } \\
\text { events }\end{array}$ \\
\hline Configured & $\begin{array}{l}\text { Schema with nodes, labels, ids } \\
\text { and relationships }\end{array}$ & $\begin{array}{l}\text { Schema with nodes, labels, ids } \\
\text { and relationships }\end{array}$ & $\begin{array}{l}\text { Schema with nodes, labels, ids and } \\
\text { relationships }\end{array}$ \\
\hline Instantiated & $\begin{array}{l}\text { Instantiate asset with unique } \\
\text { ID }\end{array}$ & $\begin{array}{l}\text { Instantiate asset with unique } \\
\text { ID }\end{array}$ & Instantiate asset with unique ID \\
\hline
\end{tabular}

Table 10. Relationships and relators

\begin{tabular}{|l|l|l|l|l|}
\hline & \multicolumn{2}{|c|}{ Banking (Savings) } & \multicolumn{2}{c|}{ Loans } \\
\hline Named (Identified) & $\begin{array}{l}\text { Name of the idea and } \\
\text { context for relationship } \\
\text { (Savings account) }\end{array}$ & $\begin{array}{l}\text { Name of the idea and } \\
\text { context for relator } \\
\text { (Bank) }\end{array}$ & $\begin{array}{l}\text { Name of the idea and } \\
\text { context for relationship }\end{array}$ & $\begin{array}{l}\text { Name of the idea and } \\
\text { context for relator (Housing } \\
\text { Finance Company) }\end{array}$ \\
\hline $\begin{array}{l}\text { Defined (Concep- } \\
\text { tually Structured) }\end{array}$ & Concept of Relationship & $\begin{array}{l}\text { Concept of Role of } \\
\text { relator }\end{array}$ & Concept of Relationship & Concept of Role of relator \\
\hline Logically Designed & Related Attributes & Related Attributes & Related Attributes & Related Attributes \\
\hline Configured & Network Schema & Network Schema & Network Schema & Network Schema \\
\hline Instantiated & Account No. & $\begin{array}{l}\text { Instantiate with unique } \\
\text { ID }\end{array}$ & Account No. & Instantiate with unique ID \\
\hline
\end{tabular}


Table 11. Separations that come in the way of formal credit

\begin{tabular}{|l|l|l|l|l|l|}
\hline \multicolumn{1}{|c|}{ Informational } & \multicolumn{1}{c|}{ Capability } & \multicolumn{1}{c|}{ Spatial } & \multicolumn{1}{c|}{ Temporal } & \multicolumn{1}{c|}{ Financial } & \multicolumn{1}{c|}{ Social } \\
\hline $\begin{array}{l}\text { From borrower's } \\
\text { view-point } \\
\text { information on } \\
\text { processes may } \\
\text { be hard to access } \\
\text { and understand. }\end{array}$ & $\begin{array}{l}\text { Capability to } \\
\text { utilize funds may } \\
\text { not be there. For } \\
\text { example, starting } \\
\text { a small business } \\
\text { requires lot more } \\
\text { than mere access } \\
\text { to funds. }\end{array}$ & $\begin{array}{l}\text { Not all bank branches } \\
\text { lend. Getting a loan } \\
\text { may need multiple } \\
\text { trips to remote } \\
\text { locations }\end{array}$ & $\begin{array}{l}\text { Banks may take } \\
\text { rather long to } \\
\text { disburse loans. The } \\
\text { people may need to } \\
\text { work with Micro- } \\
\text { finance companies } \\
\text { who may charge } \\
\text { higher. }\end{array}$ & $\begin{array}{l}\begin{array}{l}\text { People may not } \\
\text { have access to } \\
\text { collateral. Only } \\
\text { accellateral. If they } \\
\text { pledge land, } \\
\text { they may lose } \\
\text { their source of } \\
\text { livelihood. }\end{array} \\
\text { are not considered } \\
\text { as trust-worthy } \\
\text { end up getting less } \\
\text { loans. }\end{array}$ & \\
\hline
\end{tabular}

Similarly, events that occur during life-time of a person can be reified and given a unique ID. These include birth, attaining maturity, migration, enrollment, emigration, immigration and death. The objectives and processes can similarly be covered.

In summary, Tantra Framework can be a useful resource to Social Scientists supporting research methods such as Action Research, Ethnography, Case Study and Grounded Theory Methods (Myers, June1997).

\section{Application Scenarios}

Tantra Framework can be used in the following Application Scenarios.

\subsection{Master Networks}

Master data on people, addresses and assets will be extremely useful for Governance in India.

\subsection{Revenue Capture}

In India tax to GDP ratio is around 10\%. Even though the number of tax payers has increased, it is a far cry from what is seen in developed countries. There is also serious underrecovery of property tax from civic bodies. Tantra Framework can help connect the dots to track under-recovery.

\subsection{Social Benefit Coverage Analysis}

Government of India provides varieties of subsidies to citizens. The targeting of subsidies is an issue. The subsidies are also subject to leakages through identity fraud and quantity fraud. Tantra Framework can provide a rich repository of credible information to do the analysis.

\subsection{Financial Inclusion}

Tantra Framework can help address issues related to Financial Inclusion.

\subsection{Metrics Analysis}

Tantra Framework enables systematic capture of Social and Economic indicators.

\section{Methodology}

Tantra Framework can be populated using data-sets available to the Government.

Table 12 gives indicative list of Data Sets of Interest to build Master Data.

Once the Primary dimensions are captured in Tantra Framework, other possible relationships can be captured using network model. These may include the relationships such as People-People, People-Assets, People-Benefits, People-Attributes, People-Locations, People-Events, People-Processes, People-Objectives, Assets-Locations, Events-Locations, Assets-Processes, Events-Processes and so on... etc. network of offices of a company as registered or reported. 
Table 12. Data sets of interest

\begin{tabular}{|l|l|l|}
\hline \multicolumn{1}{|c|}{ People } & \multicolumn{1}{|c|}{ Locations } & \multicolumn{1}{c|}{ Relators } \\
\hline Voter ID Holders & Wards & Electoral Booths \\
Aadhaar Card Holders & Assembly Constituencies & Post offices \\
Ration Card Holders & Parliamentary Constituencies & PDS Shops \\
MGNREGA Card Holders & Villages & Income tax wards \\
PAN Card holders & Towns & LPG distribution outlets \\
Passport holders & Districts & Schools, Colleges \\
LPG Consumers Data & & Phone Companies \\
PF beneficiaries & & Banks \\
Students Enrolled & & Civic bodies \\
Mobile Subscribers & & RTOs \\
Utility consumers & & Utility offices \\
Property owners & & Police Stations \\
Licensed Drivers & & Employers \\
Customers of Banks & & \\
Electricity Subscribers & & \\
Land Line Subscribers & & \\
Water connection users & & \\
\hline
\end{tabular}

\subsection{Analyzing the Data in the Framework}

To establish Master Networks, there is a need to uniquely resolve entities. For example, a person is known through IDs given by the Government, through his relationship with his family and through his relationships where he associates for a particular purpose such as education, employment, financial or medical services.

Once the entities are resolved, establishing veracity of information becomes important. At times the information may be stale. An ongoing process is needed to recertify the veracity of the information. A Social Information Management Process needs to be defined to cater to these needs.

To address revenue capture for property tax coverage we may need to collect data about owner, license-holder, type of property, legal status, mode of approved use and actual use, along with valuation and zoning information. The data can be maintained on defaulters as well those who generally comply and it can help lead to the cause of non-payment between intent and process. The tax collection offices can be relators. The status of payment of taxes can be visualized using networks and as also the tax compliance behavior of owners across tax categories.

Community wise analysis can throw insights into coverage of Social Benefit schemes. The coverage analysis can help weed out schemes that are not effective and target interventions using Theory of Change process.
The Financial Inclusion scenario can benefit using Theory of Separations approach and Metrics Analysis can be done using Balanced Scorecard Framework.

\section{Conclusions}

In this paper Ontology-based Tantra Framework is proposed with the objective to achieve Good Governance in India. Tantra Framework is architected to holistically manage social information. Tantra Framework starts with Ontology-First approach for data modeling where unique dimensions (aspects) are identified, reified through perspectives and then networked.

Tantra Framework uses Zachman Framework as reference. Even though Zachman considered his framework as ontology, some researchers regarded it as taxonomy (Nick Malik, 2012). Tantra Framework has addressed that perceived gap by extending the Zachman Framework by adding two additional columns. Using Tantra Framework, the Social Information space is modeled as discrete information space, instantiated and enumerated. The information space covers the entire gamut from concept, context, construct and instance, thus providing a single unified epiphany of information. Tantra Framework is normative frameworks that can help India realize its aspirations. Variety of people can utilize Tantra framework: Policy makers, Government Officials, Analysts, Economists, Implementers, Institutions, Ecosystem Players, people and society at large. 


\section{References}

Bartels (1968). The General Theory of Marketing, The General of Marketing, 32(1), 29-33. https://www.jstor.org/stable/1249193?seq=1\#page_scan_tab_contents.

Crawley, E. F. (2007). ESD. 34. Theory of Systems Architecture. MIT Lecture Notes.

Crawley, E., De Weck, O., Eppinger, S., Magee, C., Moses, J., Seering, W., Schindall, J., et al. (2004). The influence of architecture in engineering systems. Engineering Systems Monograph. Architecture; p. 29. https://ocw.mit. edu/courses/engineering-systems-division/esd-342-advanced-system-architecture-spring-2006/readings/ esd_architecture.pdf.

Kaplan, Robert (2010). Conceptual Foundations of the Balanced Scorecard, HBS Working Paper Series No. 10-074, March 2010. https://www.hbs.edu/faculty/Pages/item.aspx?num=37638.

Myers, Michael David (June1997). Qualitative Research in Information Systems. MIS Quarterly. https://doi. org/10.2307/249422.

Nick Malik (2009). Why the Zachman Framework is not an Ontology. https://blogs.msdn.microsoft.com/ nickmalik/2009/12/18/why-the-zachman-framework-isnot-an-ontology.

Prabhu, Shreekanth (2017). Good Governance Model. https:// www.researchgate.net/publication/325544499_Good_ Governance_Model.
Santos Jr, Paulo et.al. (2013). An ontology-based analysis and semantics for organizational structure modelling in the ARIS method. Information Systems Journal, 38(5), p. 690708. https://dl.acm.org/citation.cfm?id=2452238.

Tarafdar, Monideepa and Singh, Ramendra (December 2011). A Market Separations Perspective to Analyze the Role of ICT in Development at the Bottom of the Pyramid. Association for Information Systems. Proceedings of the Fourth Annual SIG Globdev Workshop, Shanghai, China.

Weiss (1995). Nothing as Practical as Good Theory: Exploring Theory-Based Evaluation for Comprehensive Community Initiatives for Children and Families. In: 'New' Approaches to Evaluating Community Initiatives, Concepts, Methods, and Contexts, Edited by Connel, Kubisch and Scorr, The Aspen Institute. ISBN 0-89843-167-O

Zachman, John A (2003). Zachman Framework, A Primer for Enterprise Engineering and Manufacturing. Available at http://www.zachmaninternational.com.

Zachman, John A (2007). The Framework for Enterprise Architecture: Background, Description and Utility. https://www.zachman.com/resources/ea-articles-reference/327-the-framework-for-enterprise-architecture-background-description-and-utility-by-john-a-zachman. 